\title{
Treatment of Riga-Fede disease using laser therapy: clinical case report
}

\author{
Tratamento de lesão de Riga-Fede com laserterapia: relato de caso clínico
}

Daniela Calumby da SILVA ${ }^{1}$

Patricia Moreira de FREITAS²

Ana Flávia Bissoto CALVO²

Thaís GIMENEZ ${ }^{3}$

Mônica ZANOLA'

José Carlos Petorossi IMPARATO'

\begin{abstract}
Neonatal teeth arise in the oral cavity in up to 30 days of life. Early eruption of teeth associated with dental trauma on the ventral surface of the tongue during breastfeeding may lead to a set of signs and symptoms called the Riga-Fede lesion, which manifests as a chronic ulceration on the ventral surface of the tongue. Establishing the treatment plan is a challenging task. The pediatric dentist and pediatrician, should act in promoting health and recovery of the baby with the disease, taking care not to neglect the weight loss in newborns. The aim of this study was to demonstrate the clinical implications of a Riga-Fede lesion and treatment approach using laser therapy. A 43-day-old child was referred to pediatric dentistry, presenting weight loss and a congenital lingual injury caused by a neonatal tooth. The treatment, after radiographic examination was extraction of tooth 71, topical application of Triacinolone acetonide and laser therapy. Laser therapy has been shown to be a possible treatment option for Riga-Fede lesions, reducing the healing time to four days, allowing the return to feeding and improvement in the pain symptoms from the first day of application.
\end{abstract}

Indexing terms: Low-level light therapy. Oral Ulcer. Tooth deciduous.

\section{RESUMO}

Os dentes neonatais surgem na cavidade oral em até 30 dias de vida. A erupção precoce dos dentes associado ao trauma dental na língua durante a amamentação pode levar a um conjunto de sinais e sintomas chamado de lesão de Riga-Fede, que se manifesta como uma ulceração crônica no ventre da língua. O estabelecimento do plano de tratamento é uma resolução desafiadora. O odontopediatra, bem como o pediatra, deve atuar na promoção de saúde e recuperação do bebê com a doença instalada, com o cuidado de não negligenciar a perda de peso em neonatos. O objetivo desse trabalho foi demonstrar as implicações clínicas de uma lesão de Riga-Fede e abordagem de tratamento utilizando a laserterapia. Uma criança de 43 dias foi encaminhada para tratamento com odontopediatra, apresentando perda de peso e uma lesão no ventre lingual ocasionada por um dente neonatal. O tratamento efetuado, após exame radiográfico, foi a exodontia do elemento dental 71 , aplicação tópica de Triacinolona acetonida e laserterapia. A laserterapia mostrou-se uma possível opção de tratamento para lesões de RigaFede, reduzindo o tempo de cicatrização para quatro dias, possibilitando o retorno à alimentação e melhora da sintomatologia dolorosa desde o primeiro dia da aplicação.

Termos de Indexação: Terapia com luz de baixa intensidade. Úlceras orais. Dente decíduo.

\section{INTRODUCTION}

Natal and neonatal teeth are present at birth or erupt in the first month of life, respectively'. Their etiology is a topic that is still being discussed, and their correlation with hereditary and environmental factors and some syndromes has been reported ${ }^{2-3}$, with an incidence of natal and neonatal teeth ranging from 1:2000 to 1:3500 live births. The teeth commonly affected are the mandibular central incisors, and clinically they may present a reduced size, conical shape and yellowed, with hypoplastic enamel and poor or absent root formation ${ }^{4}$.
Repetitive trauma of the tongue by these teeth during breastfeeding may cause ulceration on the ventral surface of the tongue ${ }^{5}$ and may interfere in feeding the child. This change is known as Riga-Fede disease ${ }^{6}$, traumatic lingual ulceration, eosinophilic granuloma of the tongue. Sublingual fibrogranuloma or traumatic atrophic glossitis? In the presence of these lesions, complications such as discomfort during feeding, laceration of the mother's breasts, deglutition or aspiration of the teeth may occur ${ }^{4}$.

The decision about whether or not to keep the tooth will depend on its implantation and degree of mobility, interference in feeding, possibility of traumatic

\footnotetext{
1 Faculdade São Leopoldo Mandic, Programa de Pós-Graduação em Odontologia. Rua José Rocha Junqueira, 13, Swift, 13045-755, Campinas, SP, Brasil. Correspondência para / Correspondence to: DC SILVA. E-mail: <danielaodontopediatra@live.com>.

2 Universidade de São Paulo, Faculdade de Odontologia, Departamento de Dentística, Laboratório Especial de Laser em Odontologia. São Paulo, SP, Brasil
}

${ }^{3}$ Universidade Ibirapuera. São Paulo, SP, Brasil. 
injury to the mother's breast and ventral surface of the child's tongue, and whether the tooth is supernumerary or part of the normal series ${ }^{8}$.

Treatment of the lesion on the ventral surface of the tongue may be performed by removing the causative agent or wear on the incisal edge of the tooth by using

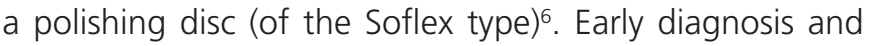
intervention prevent malnutrition, and reduce discomfort for the baby and mother, making it possible to resume feeding and complete regression of the lesion?.

Conventional therapy for Riga-Fede lesions is removal of the trauma, and topical corticosteroid application for relief of the symptoms and healing the lesion. Within this context, irradiation of the soft tissues with low level laser has been widely used, showing the potential to reduce painful sensitivity (analgesia) and accelerating the repair process in recurrent aphthous stomatitis, when compared with conventional therapies using corticosteroids ${ }^{10}$.

However, in pediatric dentistry, laser therapy is not routinely used, and may be associated with conventional therapy, promoting faster improvement in the baby's nutrition. There are no reports in the literature of the use of low level laser in Riga-Fede lesions, making this an unprecedented report in the literature. Therefore, the aim of this study was to demonstrate the clinical implications and approach to treatment using laser therapy in a case of lesion on the ventral surface of the tongue caused by a neonatal tooth.

\section{CASE REPORT}

The patient, a 43-day-old white girl was taken by her parents to a private dental service located in their city (Ipiaú, BA, Brazil), with the complaint of difficulties with breastfeeding and consequent weight loss. After anamnesis, the parents signed the term of free and informed consent with the purpose of making public images of the baby for the clinical case report.

In the clinical exam, the authors found presence of a neonatal tooth that erupted 10 days after birth (Figure 1), with mobility and presence of an ulcer located at the tip and on the ventral surface of the tongue, measuring approximately $1.0 \mathrm{~cm}$ in diameter (Figure 2). The mother reported that the child did not suck on the feeding bottle, felt pain, was irritated, hungry and unable to sleep for about 26 days. The ulcerated lesion contributed to the condition of weight loss, continual crying and prostration. The mother had consulted pediatricians who instructed her to seek pediatric dental care and make topical use of triamcinolone acetonide on the ulcerated lesion.

The radiographic exam showed that this concerned tooth 71. Due to the excessive mobility, presence of change in enamel (mineralization defect) and little root formation, the option was to extract the tooth (Figure 3). The mother was instructed to clean the affected region with $0.12 \%$ chlorhexidine without alcohol for 3 days and continue to use triamcinolone acetonide ( $3 x /$ day) until the lesion completely disappeared ${ }^{6}$. Moreover, the mother was encouraged to stimulate feeding and return on the following day for follow-up (Figure 4).

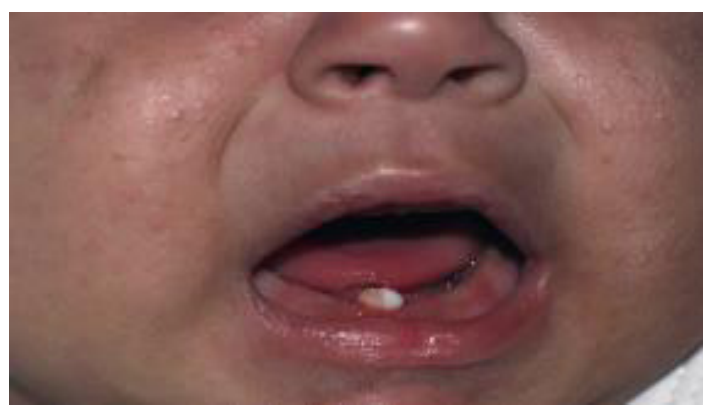

Figure 1. Aspect of neonatal tooth, hypoplastic aspect, with mobility.

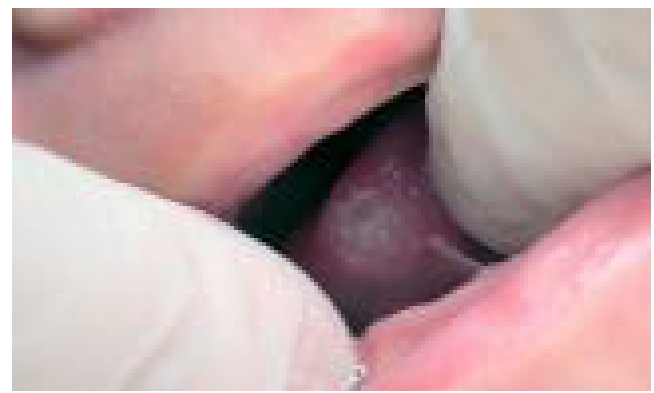

Figure 2. Traumatic ulceration on the ventral surface of the tongue.

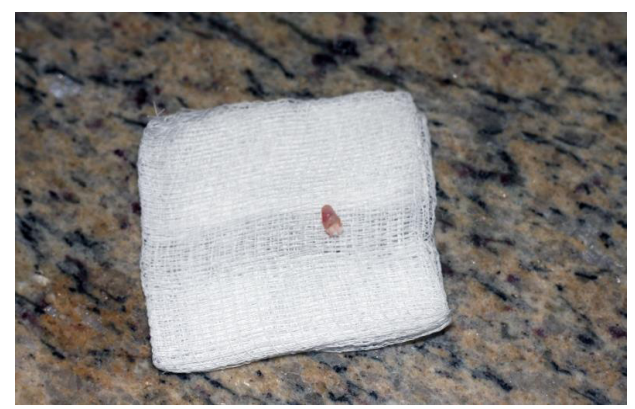

Figure 3. Tooth 71 extracted, short root and little implantation. 


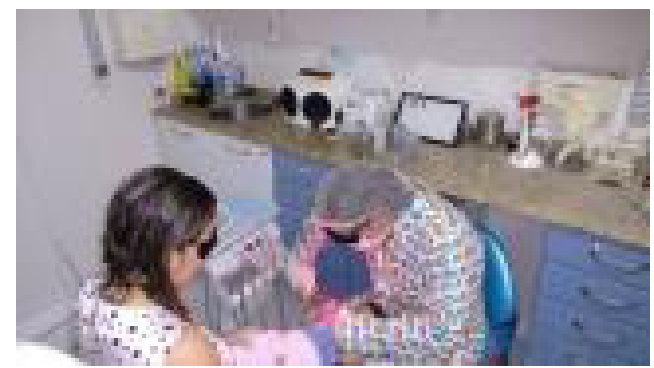

Figure 4. Consultation and follow-up.

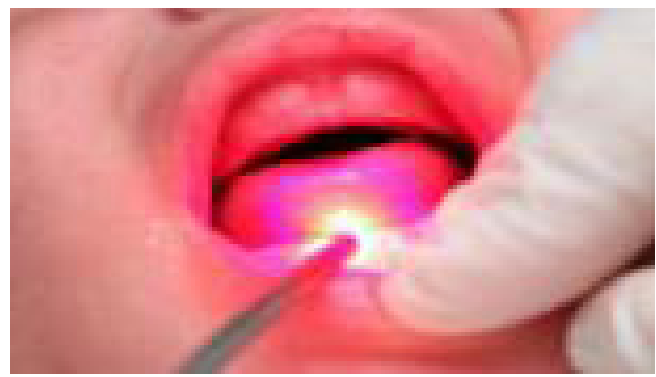

Figure 5. Aspect of neonatal tooth, hypoplastic aspect, with mobility.

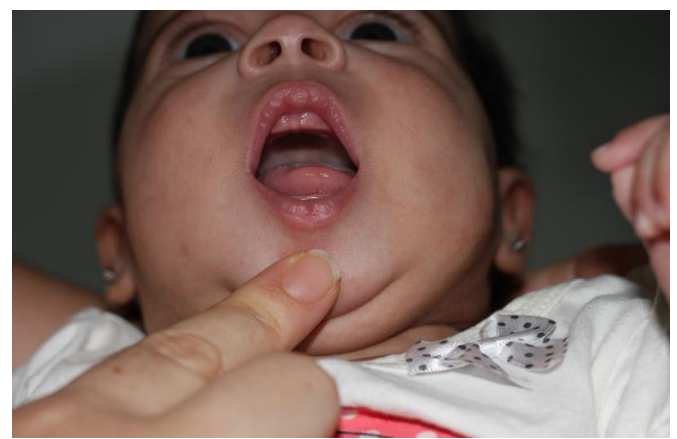

Figure 6. After the third application of laser, fourth day after extraction of tooth 71

Low level laser application was performed (Therapy, DMC Equipamentos Ltda, São Carlos-SP, Brazil). A wavelength of $660 \mathrm{~nm}$ (red) was used, emitting a power of $100 \mathrm{~mW}$ (Figure 5), $1 \mathrm{~J}$ of energy, 10 seconds per point of irradiation, on the center and on the edges of the ulceration in accordance with the protocol recommended by the manufacturer. Irradiation was performed on the day after extraction of the tooth, for three sessions on consecutive days, and continued application of triamcinolone acetonide on the ulcerated lesion to help healing and improve the painful symptoms, until the lesion healed.

According to the mother's reports, as from the first laser therapy session, the child's feeding improved, she was less irritated and without pain. After the third laser application the ulcer was healed (Figure 6). After ten days the child returned for follow-up and the mucosa on the ventral surface of the tongue had healed completely. The parents were cooperative and very satisfied with the rapid resumption of feeding and repair of the lesion.

\section{DISCUSSION}

Natal and neonatal teeth are generally diagnosed by pediatricians and early consultation with a pediatric dentist may prevent some complications ${ }^{14}$. Interaction among the professionals of the area of health allow better follow-up of the growth and development of children, providing early diagnosis and a multidisciplinary approach to health promotion ${ }^{11}$. In the case described, the child was referred by the pediatrician who had diagnosed the presence of the tooth and prescribed triamcinolone acetonide. (EMS S/A. R. Com. Carlo Mário Gardano, 450 S. B. do Campo/SP - CEP 09720-470 CNPJ: 57.507.378/0001-01 INDÚSTRIA BRASILEIRA.) However, there was no regression of the lesion because of the persistent trauma to the tongue.

The mandibular central incisors are the first teeth to erupt in the oral cavity. In cases in which they erupt early, they commonly present with little development and cone-shaped roots in the beginning of formation; they may also present enamel hypoplasia with an opaque, yellowbrown and/ or whitened color. Only 1 to $10 \%$ of natal and neonatal teeth are supernumerary ${ }^{12}$. The case reported in this article refers to a tooth of the normal series, and was in agreement with the prevalence found in the literature. Moreover, it presented an enamel mineralization defect and mobility due to the root in the process of formation.

For maintenance of the tooth in the oral cavity, it is necessary to consider some characteristics, such as the degree of mobility, implantation of the tooth and interference in breastfeeding, in addition to evaluating whether it is a supernumerary tooth ${ }^{13}$. The parents' opinion is also considered a relevant factor in the treatment decision ${ }^{3,14}$ In the present clinical case, the tooth presented little implantation in the ridge, and mobility. In view of the severity of ulceration, difficulty with feeding and the child's loss of weight, the parents agreed to the need for immediate extraction, in spite of the tooth being one of a series. The parents were instructed about the need for follow-up with a pediatric dentist to prevent future problems with occlusion.

The Riga-Fede lesion may interfere in adequate feeding (exclusive breast feeding), causing irritability, intermittent crying, weight loss, interference in the immunological system and growth ${ }^{18}$ Furthermore, it 
interferes in the capacity for suction and may lead to the child's loss of appetite, irritability and nutritional deficits ${ }^{12}$. According to the mother's report, the child was hungry and was unable to suck, her weight diminished by the day (in a period when it would be vital for weight to increase), she was in pain, cried intermittently, and had not slept for days on end.

In spite of the clinical aspect of the lesion, it was of a benign nature. The characteristics of the history of the lesion were typical and there is rarely any need for histopathological exam. To accelerate repair and improve the feeding conditions of the baby, laser therapy was suggested in the post-operative period.

The therapeutic use of low level laser has been constant in health sciences. This is due to its antiinflammatory, analgesic, anti-edematous effects and its contribution to tissue repair. The main objective of laser therapy is to normalize the tissue repair process, by promoting an increase in peripheral circulation, accelerating the formation of granulation tissue by proliferation of fibroblasts and stimulating neovascularization; consequently it is capable of promoting an increase in the input of nutritional elements into the tissue, interfering positively in the inflammatory process and favoring tissue repair. The clinical application of low level lasers for the treatment of acute and chronic pain is also a well established procedure ${ }^{15}$. De Souza et al. ${ }^{10}$ evaluated the effect of low level laser on the control of pain and repair of recurrent aphthous stomatitis. The results revealed that $75 \%$ of the patients reported a reduction in pain immediately after the treatment with laser, and complete regression of the lesion occurred after 4 days; on the other hand, complete regression in the corticosteroid group occurred in 5 to 7 days. There are reports of the use of laser in traumatic lesion of the upper lip in a patient with progressive supranuclear paralysis ${ }^{16}$, but there are no cases in the literature about the use of laser in Riga-Fede lesions. In this case report, repair of the ulcerated lesion occurred with the association of treatments: extraction of tooth 71, laser therapy and triamcinolone acetonide (EMS S/A R. Com. Carlo Mário Gardano, 450 S. B. do Campo/SP - CEP 09720-470 CNPJ: 57.507.378/0001-01 INDÚSTRIA BRASILEIRA.) The lesion healed in 4 days and according to the mother's report, the child began to feed normally and sleep better right from the first application of laser.

There is no consensus in the literature about how the protocol of irradiation with low level lasers should be changed for children, adults and older persons. Considering the faster metabolism presented by children, and consequently, a rapid healing, it is possible to conceive that lower energies than those used in adults and older persons may obtain good results ${ }^{17}$. However, in the absence of clinical studies in children, which define an appropriate irradiation protocol, in the present case report, the authors opted to use the assisted mode (indication for aphtha) suggested by the equipment manufacturer. Further studies are necessary to establish clinical protocols and spread the laser therapy technique more widely as a routine treatment.

Laser therapy has advantages, such as presenting no side effects, being a non-invasive technique that is easily applied, and one that does not generate heat in the irradiated tissue. These characteristics assure good acceptance by individuals, in addition to being reported to be a promising and safe therapy if performed by a qualified professional ${ }^{15}$.

Moreira \& Gonçalves ${ }^{6}$ described the use of triamcinolone associated with V.A.S.A. $600 \mathrm{mg}$ Gentian Violet; $1.5 \mathrm{ml}$ Anesthesine 2\%; $0.5 \mathrm{ml}$ Saccharine and water q.s.p.30 ml) and reported complete healing after ten days of treatment. In our clinical case, the mother reported improvement in the symptoms right from the first application, and after 4 days the lesion was healed. The child was able to feed, gain weight, developed correctly and her general conditions were normalized. No other studies that had used laser therapy in a Riga-Fede ulcer were found in the literature, making direct comparison impossible, but this case report presented positive results with the association of treatments.

\section{CONCLUSION}

Riga-Fede lesion is associated with the present of neonatal teeth and laser therapy appears to have contributed positively to successful treatment, reducing the time of healing, making it possible for the child to resume feeding and improving the painful symptoms.

\section{Collaborators}

DC SILVA - conducting the clinical case and writing the article. PM FREITAS, T GIMENEZ, M ZANOLA and JCP IMPARATO, revision of the scientific article. AFB CALVO, guidance and review of the article. 


\section{REFERENCES}

1. Simões GAM, Mendes LD, Oliveira SMM, Penido CVSR. Relato de caso clínico de paciente com dente natal e neonatal. Assoc Paul Cir Dent. 2014;68(4):328-30.

2. Kana A, Markou I, Arhakis A, Kotsanos N, Natal and neonatal teeth: a systematic review of prevalence and management. Eur J Paediatr Dent. 2013;14(1):27-32.

3. Mhaske S, Yuwanati MB, Mhaske A, Ragavendra R, Kamath K, Saawarn S. Natal and neonatal teeth: na overview off the literature. ISRN Pediatr. 2013;2013:956269. doi: $10.1155 / 2013 / 956269$

4. Leung AKC, Robson WLM. Natal teeth: a review. J Natl Med Assoc. 2006;98(2):226-8.

5. Meij EHVD, Vries TWD, Eggink HF, Visscher JG. Traumatic lingual ulceration in a newborn: Riga-Fede disease. Ital J Pediatr. 2012;38:20. doi: 10.1186/1824-7288-38-20

6. Moreira FCL, Gonçalves IMF. Dentes natais e doença de RigaFede. RGO, Rev Gaúcha Odontol. 2010;58(2):257-261.

7. Costacurta M, Maturo P, Docimo R. Riga-Fede disease and neonatal teeth. Oral Implantol (Rome). 2012;5(1):26-30.

8. Khandelwal V, Nayak UA, Nayak PA, Bafna Y. Management of an infant having natal teeth. BMJ Case Rep. 2013;31-3.. doi: 10.1136/bcr-2013-010049.

9. Volpato LER, Simões CAD, Simões F, Nespolo PA, Borges AH. Case Report Riga-Fede Disease Associated with Natal Teeth: Two Different Approaches in the Same Case. Case Rep Dent. 2015;2015:234961. doi: 10.1155/2015/234961.

10. Dezan CC, Walter LRDF, Gasparoni KW, Sangiorgio JPM, Nogari $B$, Fernandes KBP. Sublingual traumatic ulcerative lesions caused by the eruption of primary mandibular molars: a case report. Int J Morphol. 2011;29(4):1136-1138.

11. Diniz MB, Gondim JO, Pansani CA, de Abreu e Lima FCB. A importância da interação entre odontopediatrias e pediatras no manejo de dentes natais e neonatais. Rev Paul Pediatr. 2008;26(1):64-69.

12. Basavanthappa NN, Kagathur $U$, Basavanthappa RN Suryaprakash ST. Natal and neonatal teeth: a retrospective study of 15 cases. Eur J Dent. 2011;5(2):168-72.

13. Kamboj M, Chougule R B. Neonatal tooth-how dangerous can it be? J Clin Pediatr Dent. 2009;34(1):59-60.

14. Malki GA, Al-Badawi EA, Dahlan MA. Natal teeth: a case report and reappraisal. Case Rep Dent. 2015;2015:147580. doi: $10.1155 / 2015 / 147580$

15. Vazzoller RMS, Fernandes RD, de Sena RMM, de Sena AM Tratamento do herpes simples por meio da leserterapia: relato de casos. Rev Cient ITPAC. 2016;9(1):1-11.

16. Ribeiro MTF, Silveira LB, Moreira AN, Ferreira EF, Vargas AMD, Ferreira RC. Cuidados odontológicos na paralisia supranuclear progressiva: relato de caso. Rev Bras Geriatr Gerontol. 2012:15(2):381-8. doi: 10.1590/S1809-98232012000200019.

17. Machado MAAM, Sakai VT, Silva TC, Tessarolli V, Carvalho FP, Morretti ABS, Santos CF, Oliveira TM. Therapeutic lasers in surgical procedures of pediatric denttistry: case reports. J Oral Laser Applications. 2010;10:175-180.

Received on: 15/4/2016 Final version resubmitted on: 3/7/2016 Approved on: 7/12/2016 